\begin{tabular}{|c|c|c|}
\hline Beitr. Ent. & Keltern & ISSN 0005-805X \\
\hline $\mathbf{6 2}(2012) 1$ & S. $225-233$ & 15.05 .2012 \\
\hline
\end{tabular}

\title{
Distributional notes on Chrysomelidae from Pakistan and Afghanistan
}

\section{(Coleoptera)}

\author{
Konstantin Nadein, ${ }^{*}$ Zubair Ahmed and Maxim Sergeev
}

\begin{abstract}
Summary
The distributional data concerning 19 species from Pakistan and 9 species from Afghanistan are presented. Eight species are recorded as new for Pakistan: Coptocephala crassipes (Lefevre, 1876), Chloropterus ornatus Lopatin, 1984, Pachnephorus tesselatus Duftschmidt, 1825, Macrocoma sacra (Lopatin, 1983), Macrocoma marquardti (BReIt, 1913), Palpoxena pallida (JaCoBy, 1896), Aulacophora impressa (FABRicius, 1801), and Chaetocnema belli JАCOBY, 1904. One species is recorded as new for Afghanistan: Tituboea heptneri (Medvedev, 1957).

\section{Zusammenfassung}

Die Verbreitungsdaten von 19 Arten aus Pakistan und 9 Arten aus Afghanistan werden präsentiert. Acht Arten werden als neu für Pakistan gemeldet: Coptocephala crassipes (Lefevre, 1876), Chloropterus ornatus Lopatin, 1984, Pachnephorus tesselatus Duftschmidt 1825, Macrocoma sacra (Lopatin, 1983), Macrocoma marquardti (Breit, 1913), Palpoxena pallida (JACOBY, 1896), Aulacophora impressa (FABricius, 1801), und Chaetocnema belli Jасову, 1904. Eine Art wird in Afghanistan neu nachgewiesen: Tituboea heptneri (Medvedev, 1957).
\end{abstract}

Key words

Chrysomelidae, leaf beetles, Pakistan, Afghanistan, distribution, new records

\section{Introduction}

The faunistic data on the leaf beetles of Pakistan are still sufficiently incomplete; the majority of species are recorded once for this territory and their distributional pattern is unknown. The only existing summary by Hashmi \& Tashfeen (1992), and also Chaudry et al. (1966), as well as identification keys of AbDullah \& Qureshi (1968, 1969a, 1969b) lack exact geographical data. The leaf beetles of Afghanistan are studied somewhat better (see e.g. Gruev 1988; Lopatin 1962, 1983; Medvedev 1978, 1985), although real distributional data is also fragmentary. The general faunistic records on the Chrysomelidae of Pakistan and Afghanistan are summarized in LöBl \& SMETANA (2010).

\footnotetext{
* corresponding author.
} 
The new findings of leaf beetles presented below supplement data on the ranges of the species and especially their distributional pattern in Pakistan and Afghanistan. It has the special interest in view that both regions are situated at the border between Palaearctic and Oriental zoogeographical regions.

\section{Material and Methods}

The identification of material was carried out using works of MAulik $(1926,1936)$, MedvedeV (1962), Abdullah \& Qureshi (1968, 1969a, 1969b), Lopatin (1977), WarchaŁOWski (1991, 2003).

The material from Pakistan treated in this paper was collected by second author and housed in the Natural History Museum, University of Karachi; the material from Afghanistan was collected by O. V. PAK (Donetsk, Ukraine) and stored in the personal collection of the third author.

\section{Results}

\section{Subfamily Clytrinae}

\section{Coptocephala crassipes iranica (MEDVEDEV, 1971)}

\section{New record:}

N. Pakistan, Khyber-Pakhtunhwa Province, Mansehra District, Balakot, 20.IV.2009, 1 male.

New to Pakistan. Described from Iran and distributed also in Afghanistan, India, Oman, Saudi Arabia and Yemen. The nominotypical subspecies is distributed in Italy (Sardinia) and North Africa (Löbl \& SMetana 2010).

\section{Smaragdina viridis viridis (KRAATZ, 1882)}

\section{New record:}

Afghanistan, Kabul Province, Kabul environs, Parman gorge, 18.05.2010, 3 exx.

Previously recorded in Afghanistan from Herat Province (Medvedev 1978). Distributed also in Middle Asia (Löbl \& Smetana 2010).

\section{Tituboea heptneri (MEDVEDEV, 1957)}

\section{New record:}

Afghanistan, Kabul Province, 5 km NW Kabul, Kargha locality, 2000 m, 15-16.05.2010, 3 exx.; the same place, 1-2.06.2010, 2 exx.

New to Afghanistan. Described from Iran. This species is insufficiently studied and poorly known. The finding of this species in Afghanistan suggests of its larger range. The material examined supplements with data on the variability of colouration of this species: pronotum with or without two blurred piceous spots at basal margin, 4 dark spots on elytron vary in size from medium-sized to small, dot-shaped, legs and last segment of abdomen black or legs entirely yellow. 


\section{Tituboea silensis (WEISE, 1894)}

New record:

Afghanistan, Kabul Province, 5 km NW Kabul, Kargha locality, 2000 m, 15-16.05.2010, 1 ex. Previously reported from Afghanistan from Kabul environs, Laghman and Ghazni Provinces (Medvedev 1978).

\section{Labidostomis nuristanica REINECK, 1937}

New record:

Afghanistan, Kabul Province, 5 km NW Kabul, Kargha locality, 15-16.05.2010, 8 exx.

This polytypic species comprises three subspecies including the nominotypical. The differences between them are indistinct including aedeagal. Hence, it is difficult to identify the subspecies of examined material, though the colouration the most resembles Labidostomis nuristanica afghanica L. Medvedev, 1978. All subspecies are distributed mostly in Afghanistan (Löвl \& Smetana 2010) which gives objections against their validity; this subspecies also known from Pakistan.

\section{Subfamily Eumolpinae}

Platycorynus peregrinus (HERBST, 1783)

New record:

NE Pakistan, Punjab Province, Rawalpindi District, Murree environs, 15.VIII.2009, 1 ex.

Previously reported from Pakistan by НАsнmi \& TAshfenn (1992) without exact geographical data. The species is widely distributed in the Oriental Region (Löbl \& Smetana 2010).

\section{Chloropterus ornatus Lopatin, 1984}

\section{Material:}

E Pakistan, Sindh Province, Umerkot District, Umerkot environs, 15.VI.2009, 1 female.

New to Pakistan. The species is described from south-east Iran. The specimen differs from the type series by the absence of an inner spot on the elytra and the somewhat smaller size $-4.5 \mathrm{~mm}$.

\section{Pachnephorus tesselatus DufTSCHMIDT, 1825}

\section{Material:}

E Pakistan, Sindh Province, Mirpur Khas District, Tamdajam environs, 22.VI.2009, 1 ex.

New to Pakistan. The species is widely distributed in the Palaearctic Region (LöBl \& SMETAna, 2010) and known from the territories bordering Pakistan - Afghanistan and China (Medvedev 1985; Gruev 1988). 


\section{Colasposoma ornatum JАСОВY, 1881}

\section{Material:}

NE Pakistan, Punjab Province, Rawalpindi District, Murree environs, 15.VIII.2009, 3 ex.

Previously recorded for Pakistan after Hashmi \& Tashreen (1992) without exact geographical data. Known also from Afghanistan and India (Medvedev 1985).

\section{Macrocoma sacra (LOPATIN, 1983)}

\section{Material:}

N. Pakistan, Khyber-Pakhtunhwa Province, Swat District, Charbagh environs, 07.VII.2010, 1 male.

New to Pakistan. The species was described from Saudi Arabia.

\section{Macrocoma marquardti (BREIT, 1913)}

\section{Material:}

N. Pakistan, Khyber-Pakhtunhwa Province, Malkandi, Naran environs, 18.VI.2010, 1 male, 2 females.

New to Pakistan. The species is distributed in China (Tibet) and Afghanistan (Medvedev 1985; Gruev 1988; Löbl \& Smetana 2010).

\section{Chrysochares asiaticus (PALLAS, 1771)}

New record:

E. Afghanistan, Nangarhar Province, 10 km SE Jalalabad, Samarkhel Village, Kabul River valley, 13.05.2010, 2 exx.

Previously reported as Chrysochares asiaticus orientalis Lopatın, 1963 in Afghanistan from Maimana Province. This information was missing in the Catalogue of Palaearctic Coleoptera (Löbl \& Smetana 2010). Mostly asiatic species are known also from the south of the European part of Russia, Ukraine, Azerbaijan, Kazakhstan, Mongolia, Middle Asia, and from Xinjiang Province of China (Löвl \& SMETANa 2010).

\section{Subfamily Chrysomelinae}

\section{Chrysolina punjabiensis Abdullah \& QUREShI, 1968}

New record:

N. Pakistan, Khyber-Pakhtunhwa Province, Chitral District, Boony environs, 15.VII.2010, 1 male.

Previously known from the type locality in W. Pakistan, Punjab Province, Lahore. 


\section{Chrysolina inconstans WIEDEMANN, 1823}

New record:

N. Pakistan, Khyber-Pakhtunhwa Province, Malkandi, Naran environs, 18.VI.2010, 3 females.

This species was recorded from Pakistan by Abdullah \& Qureshi (1968) and Hashmi \& Tashfeen (1992) without exact geographical data. Known also from India and Sri Lanka (BieńKowski 2001; Löbl \& SMetana 2010).

\section{Chrysolina grata grata (FALDERMANN, 1837)}

New record:

Afghanistan, Kabul Province, Kabul environs, Parman gorge, 18.05.2010, 3 ex.; Afghanistan, Kabul Province, 5 km NW Kabul, Kargha locality, 2000 m, 15-16.05.2010, 1 ex.

A common and abundant species recorded in Afghanistan from many provinces (MEDVEDEV 1985). Also known from Georgia, Iran, Iraq, Turkey, and Turkmenia (Löbl \& Smetana 2010).

\section{Chrysolina marginata circumducta (MÉNÉTRIÉs, 1835)}

New record:

Afghanistan, Kabul Province, 5 km NW Kabul, Kargha locality, 2000 m, 15-16.05.2010, 1 ex.; Afghanistan, Bamyan Province, Kokhi-Baba Mountain range, $10 \mathrm{~km} \mathrm{~S} \mathrm{Bamyan,} \mathrm{30.05.2010,}$ 1 ex.

This holarctic species is polytypic with a complicated situation within the species complex and unclear status of the most of subspecies described so far. Only the subspecies Chrysolina marginata bodemeyeri (WeIsE, 1910) has been recorded from Afghanistan from Herat, Oruzgan, Baghlan, and Kabul (Medvedev 1985). Thus, this subspecies is recorded from Afghanistan for the first time.

\section{Subfamily Galerucinae}

\section{Tribe Galerucini}

Palpoxena pallida (JАСОВY, 1896)

New record:

E. Pakistan, Sindh Province, Mirpur Khas District, Khan, 24.VII.2010, 1 male.

New to Pakistan. Previously known from India (Bombay: Belgaum). According to Abdullah \& Qureshi (1968) and Chaudry et al. (1966) three species are known from Pakistan - Palpoxena albicans (JАСОВY, 1900), P. rufofulva (JАСOBY, 1896), and P. konbirensis (WeISE, 1924). 


\section{Merista quadrifasciata (Hope, 1831)}

New record:

N. Pakistan, Khyber-Pakhtunhwa Province, Mansehra District, Paras environs, Naran Village, 27.VII.2009, 3 exx.

Previously known in Pakistan from Punjab Province (Murree) and Khyber-Pakhtunhwa Province: Hazara District (Abbottabad); also known from India and Nepal (Maulik 1936).

\section{Mimastra cyanura (Hope, 1831)}

New record:

N. Pakistan, Khyber-Pakhtunhwa Province, Mansehra District, Paras environs, Naran Village, 27.VII.2009, 2 exx.

Previously known in Pakistan from Punjab Province (Kulu) (Maulik, 1936) and KhyberPakhtunhwa Province: Hazara District (Abbottabad, Balakot) (CHAudry et al. 1966).

\section{Aulacophora foveicollis (LUCAs, 1849)}

New record:

N. Pakistan, Khyber-Pakhtunhwa Province, Mansehra District, Paras environs, Naran Village, 27.VII.2009, 1 ex.; E Pakistan, Sindh Province, Tharparkar environs, 05.VII.2008, 1 ex.

Previously known in Pakistan from Punjab Province, Khyber-Pakhtunhwa Province, and Sindh Province (Chaudry et al. 1966; Medvedev 1985). The species is widely distributed in southern Europe, North Africa, Western Asia, and India (Löbl \& Smetana 2010).

\section{Aulacophora impressa (FABRICIUS, 1801)}

\section{Material:}

E. Pakistan, Sindh Province, Tharparkar District, Nagarparkar environs, 15.VII.2010, 1 ex.

New to Pakistan. Previously known from India and Nepal (Maulik 1936; Löвl \& Smetana 2010).

\section{Aulacophora intermedia JАСОВY, 1892}

New record:

E. Pakistan, Sindh Province, Mirpur Khas District, Khan environs, 24.VII.2010, 1 ex.

Previously known from Pakistan from Khyber-Pakhtunhwa Province (Hazara District) and Punjab Province (Murree) (Chaudry et al. 1966). Distributed also in India, Sri Lanka, and Myanmar (Maulik 1936). 


\section{Radymna persica (FALDERMANN, 1837)}

New record:

E. Afghanistan, Nangarhar Province, 10 km SE Jalalabad, Samarkhel Village, Kabul River valley, 13.05.2010, 2 exx.

A common and abundant species recorded in Afghanistan from many provinces (Medvedev 1985). Widely distributed in West Asia (Löbl \& Smetana 2010).

\section{Tribe Alticini}

Altica balassogloi (JACOBSON, 1892)

New record:

N. Pakistan, Khyber-Pakhtunhwa Province, Chitral environs, 14.VII.2010, 1 male, 3 females.

Previously reported from North Pakistan in Gupis District of Gilgit-Baltistan territory (LopATIN 1967).

\section{Altica himalayensis CHEN, 1936}

New record:

N. Pakistan, Khyber-Pakhtunhwa Province, Swat District, Charbagh environs, 07.VII.2010, 4 exx.

This species was recorded for Pakistan from Punjab Povince (Murree) (DöBerl 2003). Widely distributed in West Asia: Bhutan, India, Nepal, China (Löbl \& Smetana 2010).

\section{Chaetocnema belli JACOBY, 1904}

New record:

E. Pakistan, Sindh Province, Tharparkar District, Mithi environs, 17.IX.2010, 2 exx.

New to Pakistan. Previously known from India (Bombay, Nilgiri Hills) and Nepal (Maulik 1926;

Löbl \& SMETANa 2010).

\section{Subfamily Cassidinae}

\section{Cassida subtilis WEISE, 1897}

New record.

E. Pakistan, Sindh Province, Tharparkar environs, 5.VII.2008, 26 exx.

Previously known from Pakistan after Hashmi \& TASHFeEn (1992) without exact geographical data. Distributed also in India, Sri Lanka, and Myanmar (Borowiec 1999). 


\section{Cassida brevis (WEISE, 1884)}

\section{New record:}

Central Afghanistan, Bamyan Province, Banda-Amir, 2900 m, 5 exx.

Previously reported from Afghanistan from Ghazni, Oruzgan, Ghor, and Bamyan Provinces (Medvedev 1985; Gruev 1988). Widely distributed in south-east Europe, Transcaucasus, and West Asia (Löbl \& SMetana 2010).

\section{Acknowledgements}

The authors are grateful to O. V. Pak (Donetsk, Ukraine) for the opportunity to study material from Afghanistan and C. Staines (Smithsonian Institution, Washington) for the linguistic help.

\section{References}

Abdullah, M. \& Qureshi, S. S. 1968: The Chrysomelidae, Coleoptera of Pakistan. Part III. - A key to the genera and species of the Galerucinae, with descriptions of new genera and species. - Pakistan Journal of Science and Industrial Research 11 (4): 396-414.

Abdullah, M. \& Qureshi, S. S. 1969a: A key to the Pakistani genera and species of the Hispinae and Cassidinae (Coleoptera: Chrysomelidae), with description of new species from West Pakistan including the economic importance. - Pakistan Journal of Science and Industrial Research 12: 95-104.

Abdullah, M. \& Qureshi, S. S. 1969b: A key to the Pakistani genera and species of the Chrysomelinae and Halticinae (Coleoptera: Chrysomelidae), with description of new genera and species including the economic importance. - Pakistan Journal of Science and Industrial Research 12: 105-120.

Bieńkowski, A. 2001: A study of the genus Chrysolina Motschulsky, 1860, with a checklist of all the described subgenera, species, subspecies, and synonyms (Coleoptera: Chrysomelidae: Chrysomelinae). - Genus 12: 105-235.

Borowiec, L. 1999: A world catalogue of the Cassidinae (Coleoptera: Chrysomelidae). - Biologica Silesiae, Wroclaw.

Chaudry, G.-U.; Chaudry, M. I. \& Khan, S. M. 1966: Survey of insect fauna of forests of Pakistan. Final technical report. - Biological sciences research division, Pakistan forest institute, Peshawar, 167 pp.

DöвerL, M. 2003: Alticinae from India and Pakistan stored in the collection of the Texas A. \& M. University, U.S.A. (Coleoptera, Chrysomelidae). - Bonner zoologische Beiträge 51 (4): 297-304.

Gruev, B. 1988: Check-liste der Arten von Eumolpinae, Chrysomelinae, Alticinae, Hispinae und Cassidinae in Afghanistan (Coleoptera: Chrysomelidae). - Entomological Review of Japan 43: 145-170.

Hashmi, A. A. \& Tashfeen, A. 1992: Coleoptera of Pakistan. - Proceedings of Pakistan Congress of Zoology 12: 133-170.

Lopatin, I. K. 1962: On the fauna of leaf beetles of Afghanistan (Coleoptera, Chrysomelidae). Zoologicheskiy Zhurnal 41 (12): 1811-1816 [in Russian, English summary].

Lopatin I. K. 1963: Die Chrysomeliden (Coleoptera) Afghanistans auf Grund der Ergebnisse der Forschungsreise des Herrn J. Klapperich in der Jahren 1952-1953. - Annalen Historico-Naturales Musei Nationalis Hungarici, Zoologica 55: 349-377.

Lopatin I. K. 1967: Neue Chrysomeliden-Arten aus Pakistan (Coleoptera, Chrysomelidae). - Entomologische Arbeiten aus dem Museum G. Frey 18: 323-326.

Lopatin I. K. 1977: Leaf beetles (Chrysomelidae) of Middle Asia and Kazakhstan. - Nauka, Leningrad.

Löвl, I. \& Smetana, A. (eds.) 2010: Catalogue of Palaearctic Coleoptera. Chrysomeloidea. Volume VI. Apollo Books, Stenstrup. 
Maulik, S. 1926: The Fauna of British India, including Ceylon and Burma. Coleoptera, Chrysomelidae (Chrysomelinae and Halticinae). - Taylor \& Francis, London.

Maulik, S. 1936: The Fauna of British India, including Ceylon and Burma. Coleoptera, Chrysomelidae (Galerucinae). - Taylor \& Francis, London.

Medvedev, L. N. 1962: Review of leaf beetles Antipa (Coleoptera, Chrysomelidae) of the fauna of the USSR and contiguous countries. - Entomologicheskoe obozrenie 41 (3): 613-624 [in Russian, English summary].

Medvedev, L. N. 1978: On the fauna of leaf-beetles (Coleoptera, Chrysomelidae) of Afghanistan. Entomologicheskoe obozrenie 57 (4): 859-869 [in Russian, English summary].

Medvedev, L. N. 1985: On the fauna of leaf-beetles (Coleoptera, Chrysomelidae) of Afghanistan. II. Entomologicheskoe obozrenie 59 (2):370-377 [in Russian, English summary].

WarCha£owski, A. 1991: Über die rot und schwarz gefleckten Arten der Untergattung Coptocephala s. str. (Coleoptera: Chrysomelidae: Clytrinae). - Genus 2 (3): 229-279.

Warcha£owski, A. 2003: Chrysomelidae. The leaf-beetles of Europe and the Mediterranen area. - Natura Optima Dux Foundation, Warszawa.

Author's addresses:

Ph. D. Konstantin Nadein

Department of General and Applied Entomology

Schmalhauzen Institute of Zoology

National Academy of Sciences of Ukraine

Bogdana Khmelnitskogo st. 15

$01601 \mathrm{Kiev}$

Ukraine

E-mail: luperus@mail.ru

\section{Zubair Ahmed}

Department of Zoology

Federal Urdu University of Arts

Science \& Technology, Block 9

University Road, Gulshan-e-Iqbal

75300 Karachi, Pakistan

E-mail: zahmed@gmail.com
Subject editor:

Dr. L. Zerche
Ph. D. Maxim Sergeev

Donetsk Botanical Garden

National Academy of Sciences of Ukraine

Iljicha av. 110

83059 Donetsk

Ukraine

E-mail: eksgauster@mail.ru 